of the Physical Review, though from January 1959 onwards a subscription will be charged (to members of the American Physical Society in the United States and Canada, 5 dollars ; elsewhere, 6 dollars ; to nonmembers in the United States and Canada, 10 dollars ; elsewhere, 11 dollars. Subscriptions should be addressed to the American Institute of Physics, 335 East 45th Street, New York 17, New York). The object of the new journal is to obtain speedy publication and by the use of offset printing to reduce the time between receipt and publication of the letters to two to three weeks. On the average, about fifteen letters will be accepted for each issue and only if they contain important new discoveries or cover topics of high current interest in rapidly changing fields of research.

\section{Government Museum, Madras}

The Administration Report of the fovernment Museum, Madras, for $1955-56$ (pp. vi +60 . Madras : Government Printer, 1957), states that following an intensive campaign in publicity, including posters in railway stations all over India, the number of visitors shows a marked increase of 35 per cent over the previous year. Attention has been given to courses in museum technique, and these were held in the natural sciences, archæology, anthropology and chemical conservation. Much routine work has been accomplished in each Department and re-labelling has proceeded in English and Tamil. The Museum has also been very active in its Conservation and Photographic Departments. This work includes the treatment of ancient bronze images by electrolytic methods, and lead coins with dilute acetic acid under control.

\section{Nutritional Requirements}

A NEW Food and Agriculture Organization publication (Nutritional Studies, No. 16: Protein Requirements-Report of the F.A.O. Committee, Rome, Italy, October 24-31, 1955. Pp. v+52. Rome: Food and Agriculture Organization of the United Nations; London: H.M. Stationery Office, 1957. $3 s .9 d$. net ; $0 \cdot 75$ dollars) deals with protein requirements in human nutrition. The report follows two others (No. 5, 1950; and No. 15, 1957), which considered calorie requirements. An attempt is made to assess the needs in terms of a reference high-quality protein (that from milk, eggs or meat). The report briefly discusses basic concepts such as nitrogen equilibrium, essential amino-acids and biological value. The estimated average minimum requirements, in terms of high-quality protein, range from $2 \cdot 0$ $\mathrm{gm}$. $/ \mathrm{kgm}$. body-weight in infants to $0.35 \mathrm{gm} . / \mathrm{kgm}$. for adults. To allow for individual varjations in requirement, an increment of 50 per cent is recommended, with a further allowance because the dietary protein will usually be inferior to the reference protein. A section on the practical approach deals with ways of supplementing diets poor in protein and with ways of calculating allowances. An appendix outlines suggestions for further research.

\section{Japanese Laminariaceae}

Algologists may be interested to know that the classic monograph "On the Laminariaceae of Hokkaido" (1902), by the late Dr. K. Miyabe, is now available in an English translation (J. Sapporo Agric. Coll., 1, pp. 50, with 29 plates; 1957). The monograph contains a general classification of the family and detailed descriptions of genera and species, with extensive notes on habitat and uses. The beautiful and interesting illustrations, which are a feature of the monograph, are well reproduced.

\section{New Development of Philips Gas Refrigerating Machine}

AN addition to the range of the Philips gas refrigerating machine (see Nature, 180,$892 ; 1957$ ) is announced by the distributors, Research and Control Instruments, Ltd. This new machine (the $P W 7050$ ) incorporates a nitrogen-separation column, by which means air can be liquefied and separated at atmospheric pressure to produce four litres of liquid nitrogen per hour. Continuous operation is possible for a period of one week before de-frosting becomes necessary. Special features of the $P W 7050$ are : fully automatic operation without the need of supervision; small dimensions compared with conventional equipment-the column stands approximately $6 \mathrm{ft}$. high ; risk of contamination is negligible because the air is cooled at atmospheric pressure in a single stage and does not pass through any moving parts. Further information can be obtained from Research and Control Instruments, Ltd., Instrument House, 207 King's Cross Road, London, W.C.1.

\section{Carlsberg-Wellcome Travelling Research Fellow- ships}

THE Carlsberg Foundation (Copenhagen) and the Wellcome Trust (London) announce a second series of awards of the Carlsberg-Wellcome Travelling Research Fellowships which they jointly instituted in 1957 (see Nature, 181, 743; 1958). The successful candidates for the academic year 1958-59 are Dr. S. E. Jensen and Dr. D. A. T. Dick. Dr. Jensen, of the Kommunehospitalet, Aarhus, and University of Aarhus, Denmark, will work in Prof. Russell Fraser's Department at the Postgraduate Medical School of London on the factors affecting serum lipoids in man, and Dr. Dick, from the Department of Human Anatomy, University of Oxford, will work with Prof. H. Holter at the Carlsberg Laboratory on the osmotic properties of living cells.

National Research Council of Canada : Scholarships

THE National Research Council of Canada has granted 302 scholarships for the academic year 1958-59, with a total value of 414,700 dollars. These scholarships include ninety-four bursaries worth 1,000 dollars each and 145 studentships worth 1,200 dollars each, all of which are tenable in Canada. Special scholarships awarded for study abroad include forty-six awards worth 2,000 dollars each. These special scholarships are to be held in the following countries: twenty-one in the United Kingdom, twenty-two in the United States, and one each in France, Sweden and Switzerland. Seventcen postdoctorate overseas fellowships, valued at 3,500 dollars for married and 2,700 dollars for single fellows, have been granted for work in the following countries: eleven in the United Kingdom, and one each in Belgium, France, Germany, Italy, Sweden and Switzerland.

\section{Granada Television Research Fellowship}

Granada TV Network, LtD., has offered a sum of not less than $£ 30,000$ to the University of Leeds to be spent over a period of five years in supporting 